\title{
Comparative Hypoglycemic Effects of Three Nigerian Medicinal Plants, Gongronema latifolium, Vernonia amygdalina and Viscum album on Alloxan-Induced Diabetic Mice
}

\author{
${ }^{1}$ Itelima, J. U., ${ }^{2}$ Nyam, M. A., ${ }^{3}$ Ogbonna, A. I., ${ }^{4}$ Onwuliri, E. A. and ${ }^{5}$ Maiangwa, D. T. \\ ${ }^{1,2 \& 3}$ Department of Plant Science and Technology University of Jos, ${ }^{3}$ Department of Pharmaceutical \\ Microbiology University of Jos. ${ }^{4}$ Department of Science Lab. Technology University of Jos.
}

\begin{abstract}
A study was carried out to determine the comparative hypoglycemic effects of three Nigerian medicinal plants; Gongronema latifolium, Vernonia amygdalina and Viscum album on alloxan - induced diabetic mice. Oral administration of $100 \mathrm{mg} / \mathrm{dl}$ of alloxan monohydrate produced diabetic condition in normal albino mice, which increased blood glucose level from $60.5 \pm 5 \mathrm{mg} / \mathrm{dl}$ to $156 \pm 5 \mathrm{mg} / \mathrm{dl}$, among others. The leaf extracts of G. latifolium, V. album, V. amygdalina and the combination of the 3 plant extracts had lowering effects on the blood glucose levels of the alloxan induced diabetic mice. This was done by reactivating and restoring the action of the beta-cells of the islet langerherns, which resumed their insulin production. The leaf extract of $V$. amygdalina and the combined extract became active within first hour of administration, while G. latifolium and V. album became effective in the second hour. The combined extract had more lowering effect on the blood glucose level of the diabetic mice than the other extracts. The glucose-lowering action of the three plant extracts and their combined extracts support their usage in the local treatment of diabetes.
\end{abstract}

\section{Introduction}

Hypoglycemia is the condition in which the plasma or blood glucose concentration falls below normal levels (WHO, 1999). It may arise where there is an inadequate glucose production or in cases of excessive glucose utilization (Joffe et al., 1972). On the other hand, hyperglycemia is a condition which occurs when the blood glucose level tends to be higher than the normal range. This condition is as a result of excessive glucose production, decreased glucose utilization and abnormalities in the endocrine regulation etc (Roberts, 1979).

Diabetes Mellitus is a set of related diseases in which the body cannot regulate the amount of sugar (specifically glucose) in the blood. It is a multifactor disease which is characterized by Hyperglycemia and glucosuria (Scoppola et al., 2001). Among others, these traits are hypothesized to damage cell membranes, which result in elevated production of reactive oxygen species (ROS). The generation of oxygen free radicals during cellular metabolism and by certain environment factors, including life style appears to play a critical role in the pathogenesis of diabetes mellitus (Harnett et al., 2000). Hyperglycemia, the main symptoms of diabetes, not only increases the production of ROS but also affect antioxidant reaction catalyzed by ROS scavenging enzyme systems (Kesavulu et al., 2000).

There are simply two types of diabetes mellitus. These are insulin dependent diabetes mellitus (IDDM or Type I) which is due to deficiency in synthesis and secretion of insulin from beta - cells. It is also means that the body stops providing insulin or produces very little insulin not enough to regulate blood glucose level. The other type of diabetes mellitus is the non insulin dependent diabetes mellitus (NIDDM or Type II). This is due to relative deficiency or diminished effectiveness of insulin. The pancreas secrets insulin, but the body is partially or completely unable to use the insulin. It is sometimes referred to as insulin resistance (Adler et al., 2000).

A variety of factors have been implicated as been the causal importance in the development of diabetes. These include, inheritance, infection with a specific bacteria or virus, exposure to food borne chemical toxins which can injure the pancreas, surgical removal of majority (or all) of the pancreas, increase in glucose production (from glycogen degradation) especially at appropriate times (typical cause of deranged insulin levels), decrease insulin-mediated glucose transport in muscle (primarily) and adipose tissues (receptors and post receptors defect), impair beta-cell function-loss of early phase of insulin release in response to hyperglycemia stimuli, chronic obesity, increasing age, high fat diet and physical inactivity (Jeloder et al, 2005).

The goal of management of diabetes is to avoid or minimized chronic diabetic complications, as well as to avoid acute problems of hyperglycemia. Adequate control of diabetes leads to lower risk of complication associated with unmonitored diabetes. The most prevalent form of medication is through the use of hypoglycemic agents and/or insulin therapy. There is emerging evidence that full blown diabetes mellitus type 2 can be eradicated in those with only mildly impaired glucose tolerance (Tuomilehto, 2001)

Diabetes mellitus can be treated either by using modern or traditional methods. The modern method for the treatment of diabetes mellitus involves the use of anti-diabetic drugs such as insulin, sulfonyl-ureas, 
diguanides and diet regulation which lowers glucose level in the blood (Levine, 1984, Melanderet al., 1989; Siconolfi-Baez et al., 1990). The traditional method of treatment involves the use of herbal or medicinal plants which are hypoglycemic agents (Kim et al., 2006). Laurence and Bennett (1992) reported that due to economic reasons traditional medicine is being practiced in developing countries where modern medicine is not is affordable. Also, the positive aspect of the use of medicinal plants is their low cost compare to the high price of new synthetic drug, which have become totally inaccessible to the vast majority of people living in developing countries. Another consideration in favor of the use of medicinal plants is that they do not have intense or serious side effects. Therefore, their direct administration in folk medicine offers little risk (Richard et al., 1995).

Previous studies have revealed that walnut leaf and garlic (Allium sativum) can significantly reduce fasting blood glucose level in rats with Alloxan-induced diabetes (Jeloder et al., 2005; Jeloder et al., 2009). Studies have shown that cinnamon can act significantly reducing some effects diabetes. One study that used fine ground Cinnamon cassia to treat diabetes concluded that the induction of cinnamon in the diet of people with type 2 diabetes will reduce risk factors associated with the disease (Alam et al., 2003). Other plants with hypoglycemia effects are Mormordica charantia (Sharma et al., 1960), Phaseolus vulgaris, Arctimum lappa (Charterjees, 1963), Dioscorea dumentorum (Iwu et al., 1990), Bridelia ferruginea (Okafor, 2001), Vernonia amygdalina, Viscum album, Gongronema latifolium and Panax ginseng (Bailey and Day, 1989; Ugochukwu and Babadiby, 2003a).

The search for the cure for diabetes has stimulated this work. Most of these plants are used ethnomedically as hypoglycemic agents, but some of them have not been subjected to laboratory verification. This work therefore, is aimed at the comparative verification of the hypoglycemic effects of G. latifolium, V. amygdalina and V. album on alloxan-induced diabetic mice. Alloxan is an inorganic chemical compound with a brownish-red colour, and powdery in form. It has the ability of inducing diabetic condition in animals by destroying the beta- cells of the Islets of langerherns, which is responsible for the insulin production.

\section{Collection of Plant Materials}

\section{Materials And Methods}

The leaves of Gongronema latifolium, Vernonia amygdalina were purchased from one of the markets located in Jos, Plateau State of Nigeria, while the leaves of mistletoe (Viscum album) were collected from trees in University of Jos, Nigeria. The plant species were authenticated by a plant taxonomist in the Department of Plant and Science and Technology University of Jos, Nigeria.

\section{Collection of Animals}

Twenty five albino mice, 5 week old, and average weight of 20-30g, were purchased from the Animal House University of Jos, Nigeria. The mice were acclimatized for 14 days in the laboratory and fed the normal mice feed, and water was allowed ad libitum.

\section{Preparation of Aqueous Plant Extract}

The aqueous plant extracts of the leaves $G$. latifolium, $V$. amygdalina, and $V$. album were prepared according to the method described by Okeke and Elekwa (2006). Two hundred grammes each of the leaves of the 3 plants were air-dried in the laboratory and ground into powdered with electric blender. The powdered leaves of the plants were taken separately soaked into beaker containing $400 \mathrm{ml}$ of distilled water and left to stand for $24 \mathrm{hrs}$. They were filtered with cheese-cloth. The filtrates were used for the test.

\section{Induction of Diabetes using Alloxan}

The albino mice were injected intra-peritoneal with $100 \mathrm{mg} / \mathrm{ml}$ of alloxan monohydrate per body weight of animals, in a single dose. The blood sugar level of each mouse was taken before injecting the mice with alloxan monohydrate. The actual volume administered to each group was calculated as follows, Nwachukwu and Ijeh (1999)

\section{$\%$ LD $50 x$ weight of mice \\ Concentration of alloxan}

The animals were fed freely with normal mice feed and water, this continued until a random blood glucose level was obtained on the $7^{\text {th }}$ day after injection of alloxan monohydrate, indicated a substantial rise of blood glucose level, reduced food intake, increase in fluid intake, and reduced body weight. 


\section{Administration of Plant Extracts to Albino Mice}

Treatment of the diabetes with plant extracts commence on the $8^{\text {th }}$ day, after alloxan administration. About $2 \mathrm{mls}$ of the extract was administered orally at the interval of $1 \mathrm{hr}$ for three hours every day for five days. The extract was administered using syringes (without needles). The animals were grouped into five (A, B, C, D and E) with five in each group ( $\mathrm{n}=5)$. The Group A mice were the diabetic control. They were given distilled water without plant extract. The Group B were given $V$. album (mistletoe) extract, group C were given $G$. latifolium (utazi) extract, group D were given bitter leaf ( $V$. amygdalina) extract and group $\mathrm{E}$ were given combined extracts of group $\mathrm{B}, \mathrm{C}$, and $\mathrm{D}$ in equal proportion.

\section{Blood Sample Collection}

The blood samples were collected from the albino mice by cutting the tip of their tail using scissors under aseptic condition. Blood collections were made daily, one hourly for three hours, immediately after administration of the plant extracts. Blood sugar level was also taken at zero hour, before daily treatment with the extract.

\section{Determination of Blood Glucose Concentration}

The concentrations of glucose in the blood of albino mice were determined with on-call-plus glucometer using strip method (Baker et al, 1998). The glucometer code and the strip were inserted in glucometer with an arrow indicating ready for use. A drop of blood was collected from the tip of the tail of the mice after cutting it with a pair of scissors. The blood was then dropped at one end of the strip on the glucometer. After ten second the reading was taken.

\section{STATISTICAL ANALYSIS}

The data were evaluated statistically using one way analysis of variance (ANOVA) followed by least significant difference (LSD) for test considered significant. All results were expressed as the mean for five animals in each group.

\section{Results}

Tables 1 and 2 revealed that the mean blood glucose level rose from $60 \mathrm{mg} / \mathrm{dl}$ to $156 \mathrm{mg} / \mathrm{dl}$ thus, indicating a clear manifestation of diabetic condition. The rise in the blood glucose level was accompanied by reduced mean body weight from $30 \mathrm{~g}$ to $21.5 \mathrm{~g}$ in addition to reduced mean food intake from $19 \pm 2 \mathrm{~g}$ to $16 \pm 1 \mathrm{~g}$ and increase in mean water intake from $30 \pm 2 \mathrm{ml}$ to $48.5 \pm 1 \mathrm{ml}$. During this period most the clinical symptoms of diabetes had manifested. After the administration of alloxan the rise in glucose level became more pronounced on the $5^{\text {th }}$ day with a mean concentration of $123.5 \pm 5 \mathrm{mg} / \mathrm{dl}$ and rose to $156.0 \pm 5 \mathrm{mg} / \mathrm{dl}$ on the $7^{\text {th }}$ day. Treatment of the diabetic mice with the plant extracts commence on the $8^{\text {th }}$ day, after the administration of alloxan.

TABLE 1: Conditions of the Albino Mice Recorded Daily before Alloxan Administration.

\begin{tabular}{ll}
\hline MEASURED PARAMETERS & (MEAN \pm SD) \\
\hline Weight of animals & $30 \pm 2.0 \mathrm{~g}$ \\
Weight of food intake & $19 \pm 2.0 \mathrm{~g}$ \\
Volume of water intake & $30 \pm 2.0 \mathrm{ml}$ \\
Blood glucose level & $60 \pm 5.0 \mathrm{mg} / \mathrm{dl}$ \\
\hline
\end{tabular}

(means \pm SD)

TABLE 2: Conditions of the Albino Mice Recorded Daily for Seven Days after Alloxan Administration.

\begin{tabular}{llllllll}
\hline MEASURED PARAMETERS & \multicolumn{7}{c}{ DAILY MEASUREMENT } \\
\cline { 2 - 7 } & Day 1 & Day 2 & Day 3 & Day 4 & Day 5 & Day 6 & Day 7 \\
\cline { 2 - 7 } Weight of animals $(\mathrm{g})$ & $30.0 \pm 2$ & $25.9 \pm 2$ & $24.9 \pm 2$ & $23.9 \pm 2$ & $23.5 \pm 1$ & $22.6 \pm 1$ & $21.5 \pm 1$ \\
Weight of food intake (g) & $19.0 \pm 2$ & $17.7 \pm 2$ & $17.3 \pm 3$ & $16.7 \pm 1$ & $16.5 \pm 1$ & $16.2 \pm 1$ & $16.1 \pm 1$ \\
Volume of water intake (ml) & $30.0 \pm 2$ & $32.3 \pm 2$ & $34.80 \pm 1$ & $37.6 \pm 2$ & $39.10 \pm 2$ & $43.1 \pm 3$ & $48.5 \pm 1$ \\
Blood glucose level (mg/dl & $60.0 \pm 5$ & $72.5 \pm 5$ & $74.00 \pm 3$ & $101.2 \pm 9$ & $123.5 \pm 5$ & $139.2 \pm 3$ & $156.0 \pm 5$ \\
\hline
\end{tabular}

means \pm SD

Figures 1-5 show that all the plant extracts used for the study had lowering effect on blood glucose level of albino mice. The combined extracts had the highest lowering effects, followed by $V$. amygdalina, while $V$. album had the least. The results reveal that every day, the combined extracts and V. amygdalina start reducing the glucose level of the mice on the first hour of the treatment, while G. latifolium and V. album 
became effective in the second hour. The glucose level of animals in the control was rising continuously and most of them became weak, while some entered state of coma on the fifth day. The lowest glucose levels in mice groups treated with the different plant extracts were obtained on $5^{\text {th }}$ day (Fig. 5). Hence, V. album, G. latifolium, $V$. amygdalina and the combined extracts reduced the glucose level from $148.5 \mathrm{mg} / \mathrm{dl}, 141.2 \mathrm{mg} / \mathrm{dl}$, $130.3 \mathrm{mg} / \mathrm{dl}$ and $120.3 \mathrm{mg} / \mathrm{dl}$ on day one to $141.7 \mathrm{mg} / \mathrm{dl}, 138.5 \mathrm{mg} / \mathrm{dl}, 109.6 \mathrm{mg} / \mathrm{dl}$ and $97.9 \mathrm{mg} / \mathrm{dl}$ on day five respectively. The results in Figures 1-5 also revealed that all the animals in groups B, C, D, and E remained healthy at the end of the experiment.

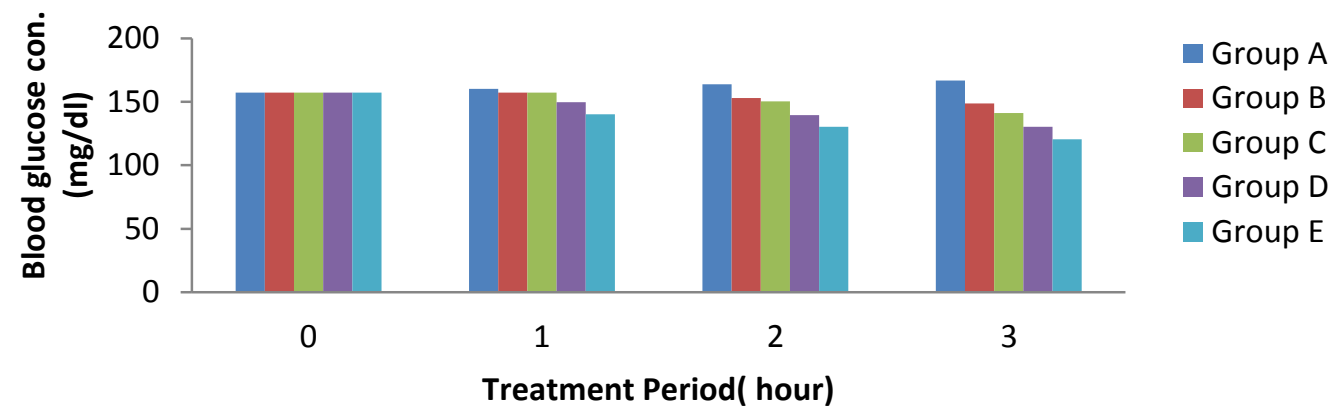

Fig. 1: Blood Glucose Levels on the First Day of Treatment with Plant Extracts

Group A= Group control, Group B= Viscum album, Group $\mathrm{C}=$ Gongronema latifolium, Group $\mathrm{D}=$ Vernonia amygdalina, Group $\mathrm{E}=$ Combined extract

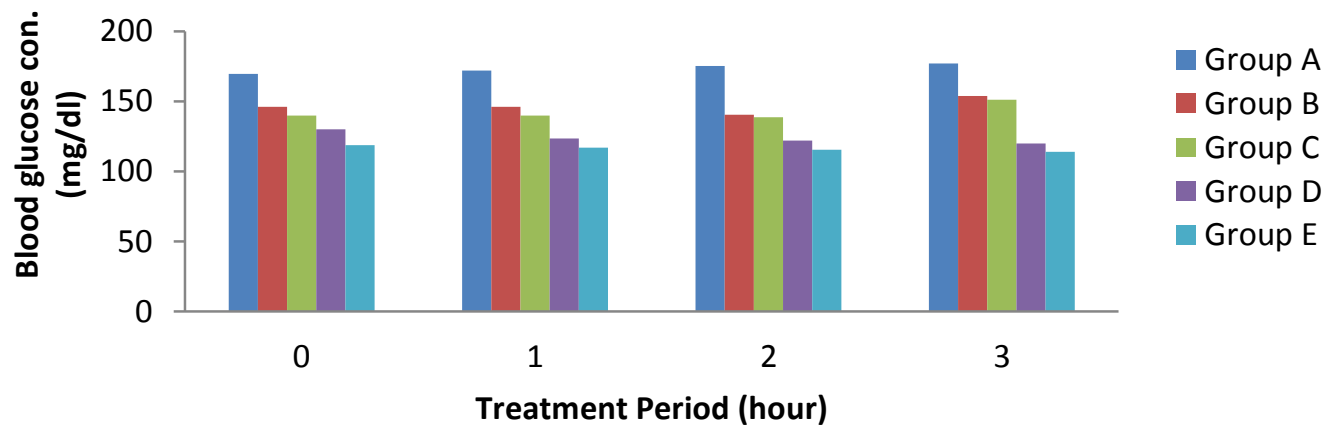

Fig. 2: Blood Glucose Levels on the Second Day of Treatment with Plant Extracts

Group A=Group control, Group B= Viscum album, Group C= Gongronema latifolium, Group D= VernoniaamygdalinaGroup $\mathrm{E}=$ Combined extract

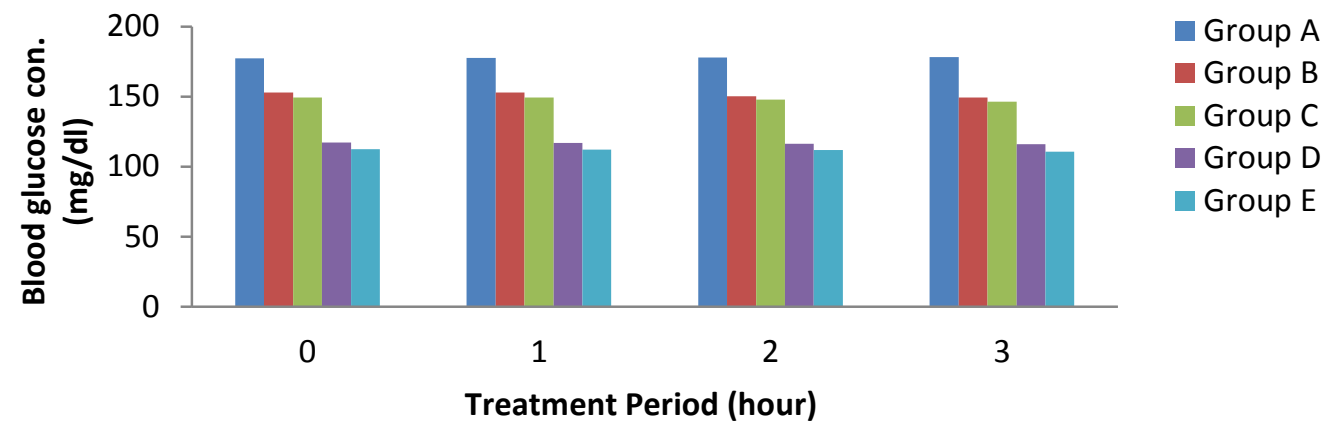

Fig. 3: Blood Glucose Levels on the Third Day of Treatment with Plant Extracts

Group A= Group control, Group $\mathrm{B}=$ Viscum album, Group $\mathrm{C}=$ Gongronema latifolium, Group $\mathrm{D}=$ Vernonia amygdalina, Group $\mathrm{E}=$ Combined extract 


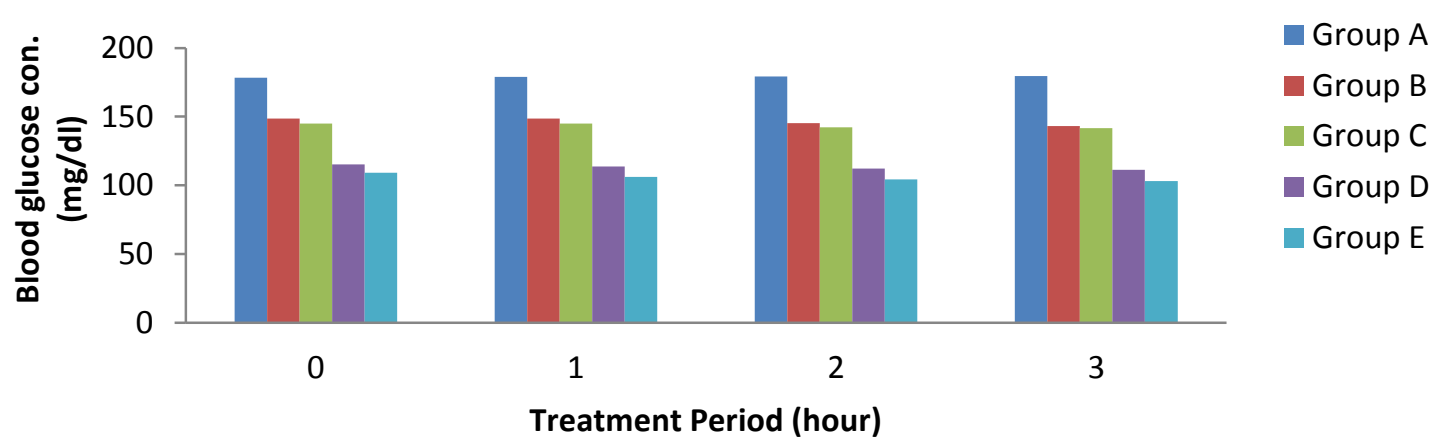

Fig. 4: Blood Glucose Levels on the Fourth Day of Treatment with Plant Extracts

Group A= Group control, Group B= Viscum album, Group C= Gongronema latifolium, Group $\mathrm{D}=$ Vernonia amygdalina, Group $\mathrm{E}=$ Combined extract

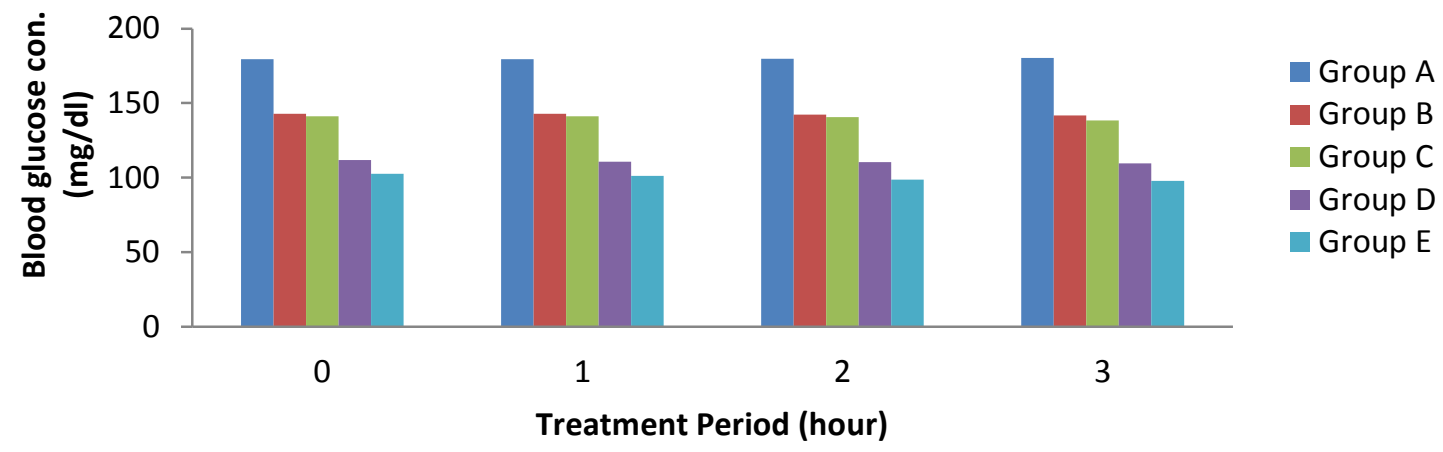

Fig. 5: Blood Glucose Levels on the Fifth Day of Treatment with Plant Extracts

Group A= Group control, Group B= Viscum album, Group C= Gongronema latifolium, Group $\mathrm{D}=$ Vernonia amygdalina, Group $\mathrm{E}=$ Combined extract

\section{Discussion}

After the administration of alloxan, there was increase in the blood glucose levels, volume of water taken by the mice, and reduction in the content of food taken. This resulted in loss of their body weight. These conditions were indications that diabetes had been successfully induced (Perez-Get al., 1996). The diabetic conditioned became more pronounced from the fifth day, following the administration of alloxan. On the seventh day, all the clinical symptoms of diabetes like reduced food intake of food, reduced body weight and increased water intake had clearly manifested.

The results of the study showed that the administration of the plant extracts led to the lowering effects on the blood glucose levels of the albino mice. This agrees with the findings of previous workers (Iwu et al., 1990; Okafor, 2001; Okeke and Elekwe, 2006). They reported that the extracts of some plants have been locally used to reduce hyperglycemic action in humans. The management of diabetes was aimed at controlling the symptoms of the disease and not to achieve cure. Glucose is the end product of carbohydrate metabolism. Excess or too low amount of glucose in the body affects the body adversely. Therefore, a certain level of glucose $(75.6-120.6 \mathrm{mg} / \mathrm{dl})$ is needed in the body systems as to maintain the health status of an individual. The fasting blood glucose will usually be $108 \mathrm{mg} / \mathrm{dl}$ in non diabetic patient, while a rise and fall in the body glucose values occur after carbohydrate meal, and these depend on the rate and result of digestion, rate of absorption and removal from circulating blood (Baker et al., 1998). The time course of glucose level was therefore linear, and dependent on the times of blood collection along with time of last meal. For this glucose to be utilized by the tissues of cells, insulin is required. Diabetes mellitus is a chronic disorder to carbohydrate metabolism, characterized by hypoglycemia, glucosuria, alteration of protein and fat metabolism. Production of polysuria, polydipsia, weight loss, ketosis acidosis and coma could be insulin resistant or insensitive even though insulin is 
present (Okeke and Elekwa, 2006). The alloxan administration caused diabetic condition, by destroying the beta-cells of the islets of langerherns, which produce insulin (Baker et al., 1998). The situation was characterized by the increase in the blood glucose concentration. The extract of three plants and the combination of the three extracts reduced the blood glucose concentration to different levels. The combined extract appears to have positive synergistic effect since it reduced the level of glucose of the mice more than the other plants did. Thus, the combination of the three extracts could provide the efficacy desired in the management of diabetes. Further studies to confirm this relative advantage of poly therapy are suggested.

The extract of V. amygdalina and combined extract showed a continuous reduction of the mice blood glucose from the on-set of its treatment. This thereafter showed a steady-state lowering of the blood glucose. The extract of V. album and G. latifolium did not start action until the second hour of each day's treatment. This means that they have had only long-term effect in the body of the mice, while the combined extract and $V$. amygdalina had both long-term and short-term effect. This suggested that the combined extract and $V$. amygdalina could be most helpful in the critical cases of treatment of diabetes

\section{Conclusion}

Conclusively, it has been shown that each of the three extracts reduced blood glucose level in diabetic animals but the combination of three extracts reduced the glucose level more than when the extracts were applied singly. Thus, proving that each of the three plant extracts had hypoglycemic effect on the diabetic mice with the combined extracts having a synergistic effect of them. For further studies, a wider range of dosage of the plant extracts should be employed for the treatment of diabetic mice. The period of administration of the extract should also be extended beyond the period used in the present study, for thorough assessment of their potency.

\section{References}

[1]. Adler, A. I., Stratton, I. M. and Neil, H.A. 2000. Association of systolic blood pressure with micro vascular complication of type 2 diabetes (UKPDS36): prospective observational study. Biomed J. 321 (7258):412-419.

[2]. Alam, K.M., Mahpara, S., Mohammed, M.A.K.., Khan, N. K., and Richard, A.A. 2008. Cinnamon Improves Glucose and lipids of people with type 2 diabetes. Diabetes care. $26: 12$

[3]. Bailey, J. C. and Day, C. 1989. Traditional plant medicine as treatment of diabetes (Review article) Diabetes Care. 120:13.

[4]. Baker, C. J. 1998. Baker and Silvertions introduction to medical laboratory technology ( $7^{\text {th }}$ ed ) Butter worth Heinmann, oxford pp 448. organic chemistry

[5]. Charterjees, K. P.1963. Studies on the presence of anti- diabetic pinnacles in Mormordica charantia. Journal of Physiology Pharmacology 7: 240-245.

[6]. Harnett, T. M., Streatton, R . D., Browne, R.W., Rosner, B. A., Lanharm, R. J. and Armstrong, D. 2000. Serum markers of oxidative stress and severity of diabetic retinopathy. Diabetes care 23:234-240.

[7]. Iwu, M. M., Okurji, C.O., Akah, P.A., Tempesta., M. S. and Corley, D.G. 1990. Dioscretein: The hypoglycemic principles of Dioscorea dumentorum. PlantaMedica. 56:119-20.

[8]. Jeloder, G.,Shahram, S. and Mohsen M. 2009. Effects of Walnut leaf, coriander and Pomegranate on Blood Glucose and Histopathology of Pancreas of Alloxan induced diabetic rats. African Journal of Traditional, Complementary and Alternative Medicines. 4(3):299-305.

[9]. Jeloder, G. A., Maleki, M., Motadayen, M. H. and Sirus S. 2005. Effect of fenugreek, onion and garlic on blood glucose and Histopathology of pancreas of alloxan induced diabetic rats. Indian Journal of Medical Science. 59 (2):64-9.

[10]. Joffe, B. I., Jackoson, W. R., Bank, S. and Vinik, A. I 979. Effects of oral hypoglycemic agent on Glucose Tolerance. In Pancreatic Diabetes Gut. 13:285-287.

[11]. Kesavulu, M. M., Kameswara, R. B. and Apparao, O. 2000. Lipid pereoxidation and antioxidant enzyme micro vascular complication. Diabetic Metabolism. 26:387-392

[12]. Kim, J. S., Ju, T. B., Choi, C. W. and Kim, B. C. 2006. Hypoglycemic and anti hypoglycemic effects of four Korean Medicinal Plants in alloxan induced Diabetic rats. A.M.J. Biochem. Biotech. 2(4) 154-160

[13]. Laurence, D. R. and Benneth, P. N. 1992. Clinical Pharmacology $6^{\text {th }}$ (ed) Singapore Book Society Limited. pp.778

[14]. Levine, R. 1984. Sulfonylurea: Background development of the field. Diabetes Care 7 (1): 3-7.

[15]. Melander, A., Bitzen, P. O., Faber. O. and Group. L. 1989. Sulphonylurea anti- diabetic drugs: an update on the clinical pharmacology and rational therapy use. Drugs. 37:58-72.

[16]. Nwachukwu, N. and Ijeh, I. I. 1999. Effect of cold aqueous extract of Azadirachta indica (A. Juss) leaves on some rat liver enzymes. Plant Product Research Journal. 4:17-12.

[17]. Okafor, J. C. 2001. Overview of tropical plants in the healthcare delivery: exploration, identification, conservation and utilization of medical plants. A paper presented at the workshop organized by association for identification, conservation and utilization of medicinal plants of Nigeria. (ASICUMPON). May 24-26, 2001.

[18]. Okeke, C. U. and Elekwa, I. 2006. Comparative hypoglycemic effects of three Nigerian vegetable spices, Gongronema latifolium Benth, Allium sativum and Ocimum gratissium Linn, on alloxan induced diabetic rats. Nigeria Journal of of Botany. 9 (1):138-146.

[19]. Perez-G, R.M., Perez-G, S., Zavala, M.A. and Perez-G, S.C. 1996. Effect of Agarista moxicana and Verbesina persicifolia on blood glucose level of normal glycemic and alloxan diabetic mice and rat. Phytotherapy Research. 10:351-353

[20]. Richard, E. S. and Siri, V. R. 1995. Ethnobotany: Evolution of a discipline Champman and Hall. 566 pp.

[21]. Roberts, M.B. V. 1979. Biology. A Functional Approach ( ${ }^{\text {nd }}$ ed $)$ ELBS and Nelson. Melbourne. 656 pp.

[22]. Scoppola, A., Montechi, F. R., Mezingr, G. and Lala, A. 2001. Urinary Mevalonate Excretion rate in type 2 diabetes, Role of Metabolic Control Atherrosclerosis. 156:357-361

[23]. Sharma, V. N., Sayamin, R. K. and Arova, R. O. 1960. Some observations on the hypoglycemic activity of Mormodica charantia. Indian. Journal of Medical Research. 48:471-475. 
[24]. Siconolfi-Baez, L,. Banerji, M. A. and Lebbvitz, H. E. 1900. Characterization and significance of sulfonulurea receptors. Diabetes Care. 13(3): 2-8

[25]. Tuomilehto, J., Lindstrom, J., Erickson J., Valle T., Hamalainen, H., Ilanne-Parikka, P., Keinanen-Kiukaanniemi. S., Laaksom, Louheranta, A., Rastas, M., Salminen, V., Uusitupa, M. 2001. Prevention of type 2 diabetes mellitus by changes in lifestyle among subjects with impaired glucose tolerance. New Eng. J on Med. 344 (18): 1343-50.

[26]. Ugochukwu, N. H. and Babadiby, N. E. 2003a. Antihypoglecemic effect of aqueous and ethanolic extracts of Gongronema latifolium leaves on glucose and streptozotocin induced diabetic rat. Life Sci. 73 (150:1925-1938)

[27]. WHO. 1999. Report of a World Health Organization technological group study series, on diagnosis and classification of diabetes mellitus and its complications WHO/DBO/DM/91.1Part. 